\title{
Panel Discussion and the Development of Students' Self Confidence
}

\author{
Khoirul Anwar ${ }^{1}$ \\ ${ }^{1}$ English Department, University of Muhammadiyah, Gresik, Indonesia \\ Correspondence: Khoirul Anwar, English Department, University of Muhammadiyah Gresik, Jl. Sumatera 101 \\ GKB Randuagung, Gresik, Indonesia. Tel: 62-813-274-18-413. E-mail: anwarkhoirul41@gmail.com
}

Received: January 10, 2016 Accepted: March 18, 2016 Online Published: March 22, 2016

doi: 10.5539/elt.v9n4p224 URL: http://dx.doi.org/10.5539/elt.v9n4p224

\begin{abstract}
This study is to analyze the use of panel discussion towards the development of students' self confidence in learning the content subject of qualitative research concept. The study uses mix-method in which questionnaire and interview are conducted at the class of qualitative research of the sixth semester consisting twenty students especially after the implementation of a lesson study project. The results show that panel discussion has potential impacts on the students' self-confidence in learning the content subject of qualitative research concept. It is also found out that the appropriate teaching procedures of the panel discussion are as follows; (1) let the students recognize learning exposures naturally by themselves (like reading research journals); (2) ask them to share, present, and discuss in a small group (in a limited number of students) to practice having mutual interaction among friends; (3) if the individuals have equipped themselves with the clear ideas of the small group, let them share in a big panel discussion. Hence, the individual self-confidence is naturally formed by the frequency of interaction among friends by sharing, discussions, and presentions.
\end{abstract}

Keywords: panel discussion, self-confidence

\section{Introduction}

There are at least two important factors that influence adult learning in the class that is cognitive and affective aspects. Cognitive is actually the ability of students to proceed information and knowledge by using brain while affective is related to very personal or individual which commonly controls learning success based on interest, motivation, and self-confidence, etc. (Brown, 2006).

The content subjects at university levels usually demand students to have activities more independently with many discussion and presentation. In this case, the characteristics of the students are highly active, proactive, and high self-confidence to accomplish all processes and activities in the class. The affective aspect of being self-confident in this case is very important to be notified at the content subjects for adult learning especially at university students (Ga, 2004; Samsudin, 2012). The ones with high self-confident have good potencies to have improved acquisition because the confidence has already made the students aware of preparing the readiness to experience the class (Mifsud, 2011). Otherwise, when the students do not have enough confidence to join the class, the danger is that they will never enjoy the learning and finally it creates the high possibility to deviate from the class (Koosha, Ketabi, \& Kassaian, 2011; Butt, Moosa, Ajmal, \& Rahman, 2011; Sabokrouh, \& Varandi , 2013).

Self-confidence is built because the students have natural experience in the process of achieving learning goals and learning process. The learning goals are important to consider because that is the initial process to orient the students to accomplish all activities easily. This goal realization usually causes easiness on realizing the process of learning especially the strategy that is offered by the lecturer (Anwar, 2015).

In fact, the choice of teaching strategy which really opens students' awareness to naturally join the process of learning is not easy. Even the most complicated teaching strategy does not always guarantee the successful engagement of the students. There should be some fundamental issues which are grounded to the successful implementation of teaching strategy in adult learners. Some experts agree that the more varieties and authenticities of the teaching procedures given to the adult classroom, this will potentially open students to create genuine creativities and learning outputs. This, in turns, automatically creates the students capacities to increase their self-confidence because they feel that the activities can be accomplished individually and easily or in group, which finally makes them enjoy the class (Anwar, 2010). 
Since the demands of students to hopefully optimize their potency in learning especially to create the maximum interaction which result students' confidence, a panel-discussion is an alternative teaching strategy that really provides the students' challenges to have more creative activities in thinking, sharing, and presenting ideas (Anwar, 2015; Mustajab, Sriyono, \& Fatmaryanti, 2012). This method is not actually new, but it seems that some teachers do not maximally optimize this as the beneficial model in teaching adult learners especially in the content-subjects at higher education in Indonesia.

The basic principles of the panel discussion is actually linear with the development of students' center learning in which the main goal of the activities is to provide students with maximum opportunities to develop their potency by optimizing interaction among friends (Anwar, 2010; Burke, 2011). The true interaction is actually to engage students' awareness that they are not alone to finish class-works, they have their potency among individuals to accomplish all the tasks (Slavin, 2014). The important point is that the students have to be encouraged to work together to maximize their potencies in any single opportunity especially in classroom interaction.

This research, therefore, is intended to analyze whether panel discussion really have potential influence of the implementation panel discussion especially in the content subject of qualitative research at English Language Education Department, University of Muhammadiyah Gresik. The second purpose is to find the appropriate teaching principles or procedures that might be useful in implementing the panel discussion in the classroom setting of adult learners.

\section{Methods}

The research is actually a mix-method of survey and descriptive research which uses two instrument types that is a questionnaire and interview. The questionnaire is of twelve items which cover the preparation-stage of learning in panel discussion that is the students' confidence to experience the limited group of discussion (small group discussion), the students' confidence in experiencing panel group discussion or the whilst or the main stage, and the students' confidence to experience the best processes or steps in learning the qualitative research of English language education department at University of Muhammadiyah Gresik. Interview is done purposively to four students who are really active and proactive joining the process of teaching-learning in the class. The main goal of the interview is not only to validate the data from questionnaire but also to confirm students' opinion about the development of self-confidence of the students and the acceptable procedures of implementing panel discussion in class.

The subjects are twenty of sixth semester students of English Education Department who are joining qualitative research in English Language Teaching. The class is chosen since it has implemented a lesson study in that the panel discussion is used during the process of teaching in the class. The classroom teaching is managed into cycles which cover four consecutive processes that is planning (preparation of classroom activities), doing (implementing the strategy of panel discussion in the class), seeing (evaluating all processes that had been conducted in the classroom procedures). The lesson study is done by a team of four teachers that are weekly scheduled of applying plan, do, and see.

\section{The Results and Discussions}

There are two types of data collection techniques to be used in this case, the first is a questionnaire and the second is an interview. The questionnaire is composed in three different categories namely the students confidence in experiencing parallel discussion (preparation stage), the students' confidence in implementing panel discussion (whilst stage), and the students' confidence to experience the best procedures in learning qualitative research (post stage). The questionnaire is created by using likert scale in which rating 1 means disagree, 2 is somewhat agree, 3 is agree, and 4 means highly agree with the statement. This questionnaire was given to 20 (twenty) students who were joining qualitative research of English education at the sixth semester. The recapitulation of the results from the students' responses is described in Table 1. 
Table 1. The students' responses of Panel discussion towards their self-confidence

\begin{tabular}{|c|c|c|c|c|c|}
\hline \multirow[t]{2}{*}{ No } & \multirow[t]{2}{*}{ Aspects } & \multicolumn{4}{|c|}{ Rating (\%) } \\
\hline & & 1 & 2 & 3 & 4 \\
\hline 1. & The purpose of learning is clear & 0 & 0 & 0 & 100 \\
\hline 2. & The journal materials to be analyzed are representative & 0 & 0 & 80 & 20 \\
\hline 3. & $\begin{array}{l}\text { The discussion in a parallel session helps me to find the detail concepts of the } \\
\text { qualitative paradigm }\end{array}$ & 0 & 0 & 90 & 10 \\
\hline 4. & $\begin{array}{l}\text { Each person in the members of parallel discussion has optimum participation to } \\
\text { bravely share ideas }\end{array}$ & 0 & 0 & 85 & 15 \\
\hline 5. & Each person is confidence to create power point presentation in parallel session & 0 & 0 & 85 & 15 \\
\hline 6. & $\begin{array}{l}\text { The process of making group conclusion is done after each individual shares ideas } \\
\text { respectively. }\end{array}$ & 0 & 0 & 80 & 20 \\
\hline 7. & $\begin{array}{l}\text { All ideas to be presented in panel discussion have represented ideas of all members } \\
\text { in group }\end{array}$ & 0 & 0 & 80 & 20 \\
\hline 8. & Every group member has equal opportunity to be the speaker in panel discussion & 0 & 0 & 90 & 10 \\
\hline 9. & I am able to create power point presentation in parallel discussion optimally & 0 & 0 & 85 & 15 \\
\hline 10. & I am personally confident to be the speaker in panel discussion & 0 & 0 & 0 & 100 \\
\hline 11. & Each person raises comments during the panel discussion & 0 & 0 & 0 & 100 \\
\hline 12. & $\begin{array}{l}\text { All procedures in panel discussion are helpful for understanding the concept of } \\
\text { qualitative research }\end{array}$ & 0 & 0 & 90 & 10 \\
\hline Tot & & $\mathbf{0}$ & $\mathbf{0}$ & 63.7 & 36.3 \\
\hline
\end{tabular}

Data of the above questionnaire shows that totally tweleve students $(63.7 \%)$ of the twenty students agree to all statements related to the confidence learning in panel discussion. The rest is about eight students $(36.3 \%)$ who highly agree to the implementation of panel discussion that it is able to enhance students' confidence in learning Qualitative Research in English Education.

It is also clearly indicated that the students have very high satisfaction $(100 \%)$ on the three important aspects namely they really recognize well on the learning purposes, the confidence to deliver ideas in the panel discussion, and they really appreciate and commit that all have raised comments and suggestions during the implementation of the panel discussion. This indicates that panel discussion really already encouraged their personal confidence to share and deliver ideas in the class.

Another important information that can be discussed is that the 18 (eighteen) students or about $80 \%$ claim that the selection of the research journals as the main materials, the fair procedure of having discussion in preparation stage (parallel session), and the representation of ideas of the panel session are fairly good. It can be taken into brief suggestion that there is an opportunity to still fulfill their expectation into highly satisfaction.

In order to support the research findings from the questionnaire, interviews are given purposively to four students who are quite proactive and responsive towards the implementation of the panel discussion. The interview is to identify two paramount issues that is about how much important the panel discussion towards their self confidence in learning, and the second is to know the acceptable procedures of the panel discussion representing the students expectations.

The students' responses about the enhancement of the self-confidence after the implementation of the panel discussion can be described by the following quotations;

Student 1;

"I think focus group discussion can increase confident because here we pursue the process one by one, I think step by step, from the easiest one to the most difficult. I think, presenting the journal is not easy to do, so, we need to practice more than one.... And ...here we present twice in the small group and the big group. As we know that in focus group discussion there are three steps; preparation, discussion in small group, and the last is discussion in a big group or panel-discussion. In parallel-discussion, each person has to read research journals, then, share the contents of the journals to the member of the group. Because the time is limited so we only focus on three main points in the journal; abstract, methodology, and results. I think, reading the journal first is a good activity because we should understand what we should present. And the second the parallel group we share 
and discuss in small group. I think presentation cannot be separated from discussion because here we do both of them especially the information that we present in the big group, after this is correct. And final discussion is the last step in focus group discussion, here, we present again, but in front of the class, and I think the information we get is better and more confident, then, before because we have prepared it in the very small group process."

The quotation above indicates that really aware that the panel discussion helps the understanding about the concept of qualitative research in English language education with the specific notes that the materials should be bottom up (from reading research journals) then analyzing them in a small group (parallel session) to make sure or to understand the details, in which each individual has to optimally understand the journal and then present and share to each other. After this process has been experienced successfully, the panel discussion then will be achieved optimally to support the self-confidence to share and to present. When the process is done smoothly, it seems that the materials are delivered properly at the right gradation therefore students find easier to learn the materials.

The similar response is also given by the second respondent especially about the reasons why the materials are important to enhance self-confidence like in the following quotation;

Student 2;

... "And eh..eh... for the strategy, I think it can increase our confidence because we begin with the small group, after reading we deliver our results of reading journal, and then the group chooses the best topic to present in front of the class. But, for myself, it's difficult enough because in implementation we get just little bit limited of time especially the focus of reading journal. As we know that to read the journal we have to get enough time to focus more, and for myself to read the journal is difficult because for myself the problem is time. And the process of the panel discussion, the first is the preparation. In the preparation, I think it is better if you read it first the journal as...eh... because we can get the main point of the journal, and now we can be confident in delivering the result of our journal. And for the second process is parallel-discussion, and in this process, eh..eh.. each member has to deliver his/her results of the journal. Maybe if there is member has difficulties they may ask to the person in this way for the process of discussion. When we discuss about our result, so..., and then the member get difficult e... ee.. difficult point for my result, you may ask and discuss together, the last is about panel e...ee... this process is e..e... the member just one of the member of the journal that will present and then e...e... it is an effective way to know confidence we are because when we can't present in a small group we will be more confidence and prepared our result in front of our class. Ok that is enough."

This second respondent actually proposes the same model of understanding the materials by rigidly follow the steps; they are initial steps which consist of individual reading of the research journals that can be presented in the parallel-discussion before it can be continued to the panel-discussion. The agreement on the lack of time for reading the journals is needed to be identified at the beginning. It seems that when the first process is not maximum, this will influence the next following stages. The second respondent also agree to the steps of implementing panel discussion by focusing on preparation of getting appropriate inputs, and then it can be followed by panel discussion after all processes have been experienced maximally. It turns out that that the steps of preparing the panel discussion are as important as the panel discussion itself. The idea is supported coincidentally by the next the third respondent who concerns with the steps;

Student 3;

... "The focus group discussion......The focus group discussion makes our confidence increase, because starting from the small group we can have discussion section and then continue to the big group. And from that we follow each step that can make us understand. And there are three steps in focus group discussion; the preparation of input and the parallel step and the panel discussion. In preparation or input we have to read the journal and I think the best way is reading the journal first and discuss to others. And the important part of the journal that become our task, the first is abstract, methodology, and result. And the second step in focus group discussion is parallel step. I think the good activity in parallel is when we can ask other members about the journal that we ...that ... they have read. And we can give suggestions. And the third step in focus group discussion is panel discussion. The good activity in panel discussion is when we are presenting results in front of all the friends in class. But after .... But before that we have to choose the best journal. And it is following the process in other at ... and then make our confidence increases."

The quotation of the third respondent even clearly states that the input process or at the preparation stage, the most important is understanding at least the general information of the journals just like understanding abstract, methodology, and findings and conclusions. Again, sharing to others at the small group of parallel discussion is a must to practice increasing students' initial confidence before presenting at the big group. 
Learning practically the concept of qualitative research is easily caught after reading research journals (even though she declares that the time to read the journal is limited still) is also supported by the fourth respondent below;

\section{Student 4;}

I think panel group discussion in lesson study yesterday, eh....eee... it is a good way to increase our confidence because it starts from the small group we can have a discussion in a small group whether we find something difficult to be answer we can have discussion in our group and eh...eee. Continue to be the big group ..... and then we have to present. Whenever the process at the first time we do such kind of preparation like we have to read the journal. But I think eh...ee.... The less of panel group discussion yesterday ... it is less of time because we have to read the journal which is the journal is so thick and then we have limited time to discuss in a small group even in a big group so the lack is only the duration of time. And then the second after reading the journal we have to discuss in a small group we have to present what we have already eh...ee. What we already get in the journal. And then the third is we have to present in a big group to all of the friends in front of the class whether they have some suggestions or questions they may ask or eh...eh... if they have suggestion they may ask or if they have suggestion may say to us what are their suggestions. I think the lack is only the duration of time. Yes thank you.

Of the four responses from respondents above, it indicates that panel discussion used during the implementation of the lesson study gives strong contribution to the increasing of students self confidence. In this case, the more the students acquire higher self-confidence, the more productive of their group performance.

Overall, this research is highly consistent with the previous studies (Koosha, Ketabi, \& Kassaian, 2011; Mifsud, 2011; Butt, Moosa, Ajmal, \& Rahman, 2011; Anwar, 2010; Sabokrouh \& Varandi, 2013) that focus on the significance influence of self confidence in learning.

This study also complements the great impacts of self-confidence towards students' verbal communication by Al-Hebaish (2012) which was conducted on 53 students majoring in English at the university of Taibah with details of the results of studies showing that there was a positive and significant connection between self-esteem and academic achievement where students who obtained a high score of questionnaire confidence also had a high score on the oral exam. Thus the students are raised to always pay attention to the importance of self-confidence to improve learning achievement. Another supporting study is done by Piran (2015) that was conducted on $92 \mathrm{EFL}$ learners in Iran Language Institute, resulting an investigation that reading comprehension ability is strongly influenced by the confidence of students, especially in the aspect of self-concept and self-esteem. The self confidence also strongly reinforces other affective factors of learning especially taking risks that were completely done by Zakia (2014) who illustrated the importance of confidence in speaking a foreign language in which the learners who have high confidence are always ready to take a risk in speaking. Conversely, low confidence students feel uncomfortable and fear and frustration in the classroom, as a result they are less effective and less satisfied in learning and ultimately affects their academic achievement.

In short, this study confirms that; (1), the implementation of the panel discussion had brought into good impact on the students' self-confidence especially during the process of individual, small group discussion, and big group (panel group discussion); (2), to achieve better results of the implementation, the procedures or steps which are rigid and comprehensive to prepare students in the objective experiences can be maximally done by facilitating the appearance of the students' awareness through creating togetherness in a small group which highly influence the positive performance in the panel group discussion.

\section{Conclusion}

The implementation of the panel group discussion in a lesson study setting on the subject of qualitative research subject at English Language Department of University of Muhammadiyah Gresik had contributed on better impact on students' self-confidence. The specific notes are identified briefly in the following conclusions;

1) Learning the theories of qualitative research by reading research journals is a good way to encourage learning centered in that students are able to naturally obtain the concept by themselves and inform the ideas in the panel discussion.

2) Self-confidence in panel discussion is developed by having more practices in a small group discussion to accustom the habit of sharing, arguing, and presenting ideas in pairs or to other limited members. Self-confidence emerges by itself when the opportunity and the frequency of sharing and discussing have been accumulated. 
3) Therefore, the better panel discussion should be implemented at least by following principles; give natural resources (like research journals) which can be the natural exposures for students to recognize, let the students share, present, and discuss at the limited members (to provides natural practices and check concepts with others) in that each individual optimally takes the roles, and finally provide the big discussion (panel discussion) to give natural opportunity of each group ideas to be met and shared. At this stage, individual self-confidence highly and naturally influences group confidence.

\section{References}

Al-Hebaish. S. M. (2012). The Correlation between General Self-Confidence and Academic Achievement in the Oral Presentation Course. Theory and Practice in Language Studies, 2(1), 60-65. http://dx.doi.org/10.4304/tpls.2.1.60-65

Anwar, K. (2010). Penguatan Self Concept siswa melalui Cooperative learning. Proceeding International Seminar: Universiti Pendidikan Sultan Idris Malaysia.

Anwar, K. (2015). A Constructive Teaching Model in Learning Research Concept for English Language Teaching Students. International Education Studies, 8(5). http://dx.doi.org/10.5539/ies.v8n5p62

Brown, D. (2006). Principles of Language Learning and Teaching. New Jesey: Pearson.

Burke, A. (2011). Group Work: How to Use Groups Effectively. The Journal of Effective Teaching, 11(2), 87-95.

Butt. Ms. Muqaddas, M., Ms. Samra, A. Muhammad, \& Rahman, F. (2011). Effects of Shyness on the Self Esteem of 9 th Grade Female Students. International Journal of Business and Social Science, 2(12).

Ga, Z. (2004). Attitudes and strategies as predictors of self-directed language learning in an EFL context. 389International Journal of Applied Linguistics, 14(3).

Koosha, B., Ketabi S., \& Kassaian, Z. (2011). The Effects of Self-esteem, Age and Gender on the Speaking Skills of Intermediate University EFL Learners. Theory and Practice in Language Studies, 1(10), 1328-1337. http://dx.doi.org/10.4304/tpls.1.10.1328-1337

Mifsud, M. (2011). The Relationship of Teachers' and Students' Motivation in ELT in Malta: A Mixed Methods Study. A thesis submitted to the University of Nottingham for the degree of Doctor of Philosophy. Retrieved from www.etheses.nottingham.ac.uk.

Mustajab, S., \& Fatmaryanti. (2012). Penerapan Metode Pembelajaran Cooperative Script Untuk Meningkatkan Partisipasi Belajar Siswa Kelas VIII A Smp Negeri 2 Karanggayam Tahun Pelajaran 2012/2013. Jurnal Pendidikan Radiasi, 1(1).

Piran, N. A. (2015). The Relationship between Self-concept, Self-efficacy, Self-esteem and Reading Comprehension Achievement: Evidence from Iranian EFL learners. International J. Soc. Sci. \& Education, $5(1)$.

Sabokrouh, F., \& Varandi, B. S. (2013). The Effect of EFL Teachers' Attitude toward English Language and English Language Proficiency on Their Sense of Efficacy. Journal of Advances in English Language Teaching, 1(4), 117-125. http://dx.doi.org/10.5539/elt.v7n1p66

Samsudin. (2012). Upaya Meningkatkan Kemampuan Memahami Cerita Melalui Keberanian Bercerita Di Depan Kelas Dengan Bantuan Media Elektronik. Jurnal Pendidikan, Dinamika, 3(1).

Slavin, R. E. (2014). Cooperative Learning and Academic Achievement: Why Does Groupwork Work? Anales de Psicología, 30(3), 785-791. http://dx.doi.org/10.6018/analesps.30.3.201201

Zakia, D. (2014). Self confidence and Pronunciation Training to Enhance the EFL Speaking Competence: A Classroom oriented Research on First-year LMD students at Abu Bekr Belkaid University, Tlemcen. Dissertation Submitted to the Department of Foreign Languages in Candidacy for the Degree of "Doctorate" in Applied Linguistics and T.E.F.L. Retrieved from http://dspace.univ-tlemcen.dz.

\section{Copyrights}

Copyright for this article is retained by the author(s), with first publication rights granted to the journal.

This is an open-access article distributed under the terms and conditions of the Creative Commons Attribution license (http://creativecommons.org/licenses/by/3.0/). 